\title{
Free Paper
}

\section{Biological effects of shock waves *}

\author{
F. Brümmer, Th. Bräuner, and D. F. Hülser \\ Abteilung Biophysik, Biologisches Institut, Universität Stuttgart, Pfaffenwaldring 57, W-7000 Stuttgart 80, Federal Republic of Germany
}

Summary. Extracorporeal shock wave lithotripsy has become established worldwide as the method of choice for the treatment of nephrolithiasis and ureterolithiasis over the last 10 years. Although initial studies showed no damaging effects of the shock waves on organs and tissues, numerous recent reports have presented evidence for severe acute effects and chronic complications after shock wave treatment. The pathophysiological effects on kidneys and the histopathological effects on organs or tissues in man and animal, and also the effects on cells in culture and tumors are sumarized. Suspended and immobilized cell cultures were used to characterize and quantify the efficacy of shock wave. Extended applications of shock waves and possible modifications to shock wave generators are discussed.

A reproducible generation of shock waves in fluids was first reported by Eisenmenger [31, 32], who described an electromagnetic arrangement using a flat solenoid and a metal membrane. About 20 years later, underwater sparkgap-induced shock waves were used for kidney stone disintegration [17], a procedure that has become clinical routine [30]. In the meantime, the third generation of lithotripters has been developed (Siemens Lithostar Plus, Dornier Compact, Storz Modulith). Most of them are equipped with electromagnetic shock-wave emitters (EMSE), but piezo-electric shock-wave sources (Piezolith 2500, Diasonics) with similar properties for stone fragmentation are also in clinical use. However, all commercially available shock-wave generators (spark gap, electromagnetic, piezo-electric) produce side effects that accompany stone disintegration in patients. Furthermore, their biological effects are described as injuries to organs or tissues in vivo that have been exposed to the focal area of shock waves and as damage to cells in culture that have been treated with shock waves.

\footnotetext{
* Dedicated to Prof. Dr. Wolfgang Eisenmenger on the occasion of his 60 th birthday
}

\section{Side effects}

In kidney- or gallstone treatment with shock waves, side effects are equivocally classified and certainly depend not only on the number and energy of the applied shock waves but also on the disposition of the patients. Petechial bleeding of the skin that can be observed macroscopically has been found in about $10 \%$ of patients [29]. Varying degrees of subcapsular fluid collection and hemorrhage have been detected using different methods $[4,37,71]$.

Most of the damage typically caused by shock-wave treatments is routinely observed and is not considered to represent severe pathological change, but the occurrence of perirenal hematoma has increased significantly in patients with pre-existing or poorly controllable hypertension [47]. Physiological tests have revealed only minor, transient reductions of renal plasma flow in the treated kidney $[45,82]$ and no clinically relevant changes in blood chemistry [17]. Furthermore, cytoplasmic enzymes have been reported to be only transiently released into the blood and urine of shock-wave-treated patients [46]. Kishimoto et al. [46] have also described an increase in creatine phosphokinase and myoglobin levels in blood on the 1st postoperative day. Their results indicate the occurrence of hemolysis, which may be due to hematomas, and myolysis, which could represent either direct damage induced by shock waves or a secondary effect caused by vasoconstriction. As a possible explanation for these side effects, cavitation $[22,35,86]$ and/or related phenomena such as free-radical production [57] have been discussed.

Hypertension has been reported to be a possible result of extracorporeal shock-wave lithotripsy [50,87], but the higher incidence of arterial hypertension following extracorporeal shock-wave treatment could not be confirmed by other investigators [5, 21, 60, 83]. A prospective, controlled study involving a large number of patients should be conducted to answer this question.

Another side effect of shock-wave treatment is pain. Principally, two types of pain are experienced during 
shock-wave lithotripsy: superficial discomfort at the surface of the skin and visceral pain in the kidney. Rassweiler and co-workers [66] reported data on pain sensation obtained during a self-trial study using a five-level dolor scale. Schneider and Ell [75] quantified the sensation of pain by randomizing volunteers, measuring their EEGs during shock-wave treatment, and interviewing these volunteers after the treatment according to the McGill pain questionnaire.

\section{Direct exposure or organs and tissues}

Organs and tissues of animals have been directly exposed to shock waves, with consequences similar to those reported for side effects: hematomas depended on the energy rather than on the number of shock waves applied and were found predominantly at the surface of organs. Acute alterations of the microcirculation have been found in shock-wave-treated Syrian golden hamsters shortly after the last discharge [10]. Larger blood vessels and the endothelial cell layers of capillaries have been damaged [10, $43]$, and vasoconstriction sometimes has been observed [10].

To date, very few published data are available on chronic pathological changes after shock-wave treatment. Experimental studies have investigated the effects of focused shock waves on canine kidneys. Newman and coworkers [61] observed hematoma and/or interstitial hemorrhage immediately after shock wave-treatment, followed 1 month later by fibrosis and chronic inflammatory cells; Jaeger et al. [43] found similar pathological changes in treated kidneys. Both studies correlate well with the data of Begun and colleagues [6], who investi- gated porcine kidneys and clearly demonstrated chronic renal injury after the application of focused shock waves. Observations of irreversible damage in the kidneys of dogs [74] and rats [68] after shock-wave treatment have confirmed the injury studies in canines and pigs.

The side effects as well as the results obtained in directly treated organs are summarized in Table 1 for the physiological interactions and in Table 2 for the histopathological effects. These results seem to contradict some findings in cell cultures, which are listed in Table 3. Most of these experiments were carried out using suspended tumor cells, which were damaged in a dose-dependent manner after being directly exposed to shock waves in the focal area.

\section{Cell cultures}

We have performed some experiments on suspended and immobilized cell cultures that enable a separation of the primary and secondary effects of shock-wave treatment $[8,9,12,13,41]$. L 1210 cells (lymphocytic mouse leukemia) have been treated as single-cell suspensions, whereas the human cervical carcinoma $\mathrm{HeLa}$ as well as the mouse mammary carcinoma EMT 6/Ro were exposed to shock waves as three-dimensionally grown multicellular spheroids. The cells were postioned in the targed focus $\left(\mathrm{F}_{2}\right)$ by a polythylene pipette. Shock waves were generated in an XL-1 lithotripter (Dornier Medizintechnik) using underwater spark discharge $(18 \mathrm{kV}, 80 \mathrm{nF}, 1 \mathrm{~Hz})$.

In cell suspension, dose-dependent damage was found that was quantified by counting the geometrically intact cells in a Coulter counter and determining the proportion of viable cells within the geometrically intact population

Table 1. Pathophysiological effects of shock waves on human and animal kidneys

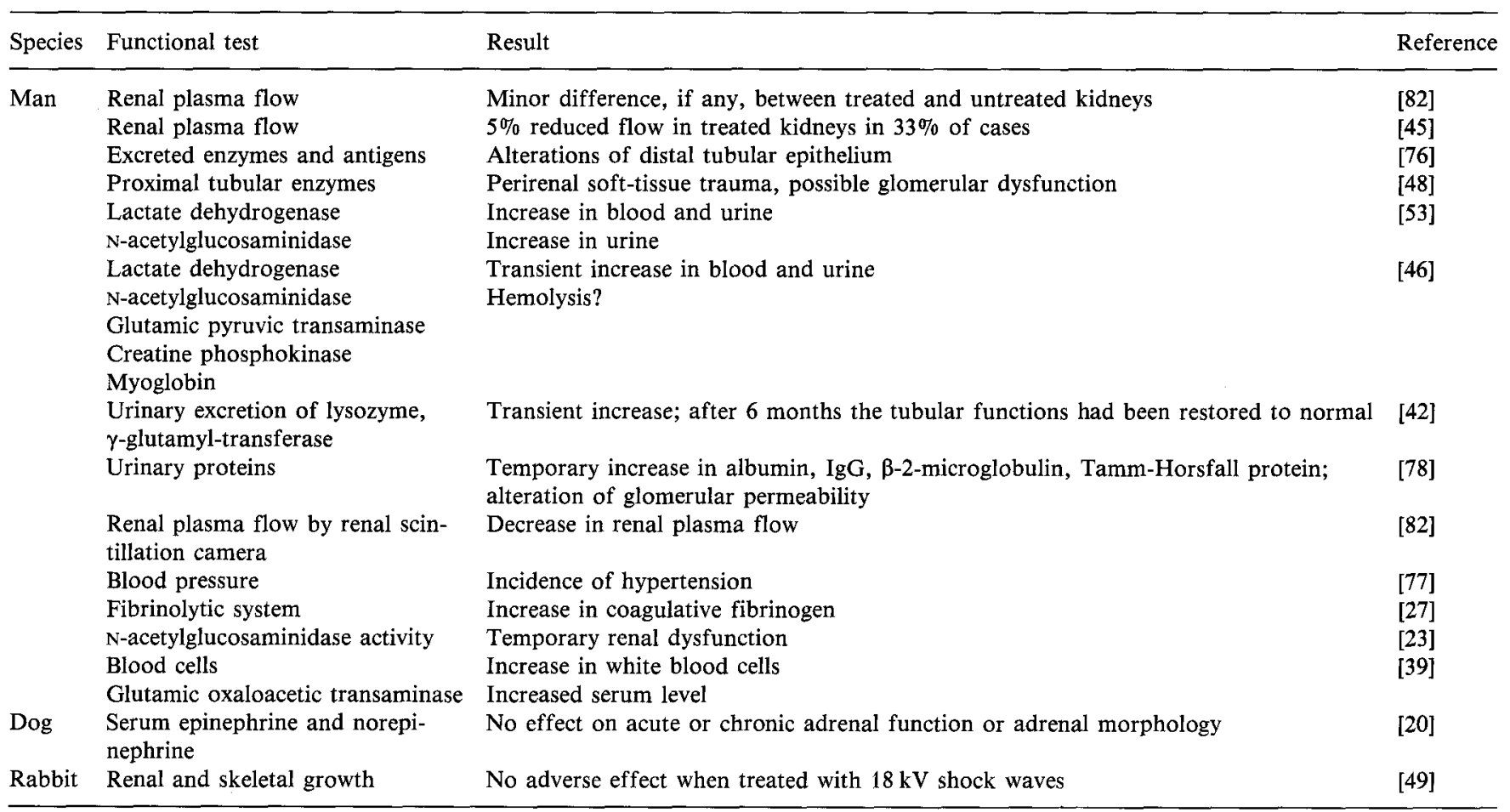


Table 2. Histopathological effects of shock waves on human and animal organs or tissues

\begin{tabular}{|c|c|c|c|}
\hline Species & Organ & Result & Reference \\
\hline \multirow[t]{10}{*}{ Man } & \multirow[t]{4}{*}{ Kidney } & $\begin{array}{l}\text { Magnetic resonance imaging: dose-dependent subcapsular fluid collections and hemorrhages, no } \\
\text { serious renal pathologic condition }\end{array}$ & [4] \\
\hline & & Computed tomography: identical results & {$[37,71]$} \\
\hline & & Magnetic resonance imaging: renal contusion, subcapsular hematoma, hemorrhage into renal tissue & [2] \\
\hline & & $\begin{array}{l}\text { Renal ultrasound, tomography, magnetic resonance imaging: perirenal hematomas (incidence of } \\
0.66 \% \text { ) increased with pre-existing and/or poor control of hypertension }\end{array}$ & [47] \\
\hline & $\begin{array}{l}\text { Cadaver } \\
\text { Kidney }\end{array}$ & $\begin{array}{l}\text { Breakdown of parenchyma; extensive vascular damage; extravasation and destruction of larger } \\
\text { vessels }\end{array}$ & [11] \\
\hline & \multirow[t]{3}{*}{ Skin } & Renal contusions & {$[45]$} \\
\hline & & Petechial bleeding at areas where SW enter the body & [29] \\
\hline & & Hemoglobinuria, decrease in renal function, local contusion, pain, focal fibrosis & [28] \\
\hline & Heart & Incidence of ventricular arrhythmias & [44] \\
\hline & Gallbladder & Serosal vasodilation, mural oedema, petechial hemorrhages, epithelial denudation & [79] \\
\hline \multirow[t]{9}{*}{ Dog } & \multirow[t]{5}{*}{ Kidney } & Linear hemorrhages extending from cortex to medulla & [1] \\
\hline & & Hematoma and/or interstitial hemorrhage, fibrosis after $8000 \mathrm{SW}$ & [61] \\
\hline & & $\begin{array}{l}\text { Hemorrhages in the inner and outer renal capsule and intraparenchymally, originating from in- } \\
\text { terlobular and arcuated veins }\end{array}$ & {$[25]$} \\
\hline & & Venous thrombosis, tubular dilatation & \\
\hline & & Slight and reversible renal tissue damage & [81] \\
\hline & Lung & Hemorrhages after gallstone destruction & [24] \\
\hline & Gallbladder & $\begin{array}{l}\text { Increase in leukocytes, alanine and aspartate amino-transferase levels; macroscopic and microscopic } \\
\text { hemorrhages; edema }\end{array}$ & [64] \\
\hline & Lung & Hemorrhages & \\
\hline & $\begin{array}{l}\text { Gallbladder } \\
\text { Liver }\end{array}$ & Small hematomas and hemosiderin deposits & [34] \\
\hline Pig & Kidney & $\begin{array}{l}\text { Interstitial capsular and perivascular fibrosis in small areas in about } 70 \% \text { of treated cases } \\
\text { Few weeks after treatment: interstitial and perivascular fibrosis with chronic lymphoid infiltration }\end{array}$ & [5] \\
\hline \multirow{19}{*}{$\begin{array}{l}\text { Syrian golden } \\
\text { hamster } \\
\text { Rat }\end{array}$} & Skin & Vasoconstriction of all arterial microvascular segments & [10] \\
\hline & Muscle & Microhemorrhage, leakage of macromolecules & \\
\hline & \multirow[t]{4}{*}{ Kidney } & Renal cortical necrosis, hemorrhages & [51] \\
\hline & & Hemorrhages, cortical tubular necorsis, cellular infiltration & [54] \\
\hline & & Loss of microvilli and cilia on cell surfaces of tubuli, cell vacuolisation, ruptures of glomeruli & [67] \\
\hline & & $\begin{array}{l}\text { Perirenal hemorrhage; } 5000 \mathrm{SW} \text { in one session: animal died; } 5000 \mathrm{SW} \text { fractionated in two sessions: } \\
\text { animal survived }\end{array}$ & [3] \\
\hline & Liver & Hepatocellular necrosis & {$[52,54]$} \\
\hline & \multirow[t]{3}{*}{ Lung } & Pulmonary interstitial cellular infiltrations & [51] \\
\hline & & Petechial bleeding & {$[17]$} \\
\hline & & Hemorrhages & [54] \\
\hline & Thorax & Massive hemoptysis and cell lesions & [17] \\
\hline & Intestine & Intestinal hemorrhages & {$[17,51]$} \\
\hline & Colon & Petechial bleeding & [17] \\
\hline & Bone & Focal growth-plate dysplasia in $44 \%$ of treated tibias & {$[90]$} \\
\hline & $\begin{array}{l}\text { Bone/ } \\
\text { femur }\end{array}$ & $\begin{array}{l}\text { Temporary dose-dependent hemorrhagic lesions; polymorphonuclear cellular infiltration; inflamma- } \\
\text { tion }\end{array}$ & [55] \\
\hline & Epidermis & Dose-dependent effects: focal hemorrhages, cellular infiltrations & [51] \\
\hline & $\begin{array}{l}\text { Ovary/ } \\
\text { fetus }\end{array}$ & Rat ovary appears to be resistant to $20 \mathrm{kV} \mathrm{SW}$ & [56] \\
\hline & Bladder & Loss of transitional epithelium caused by cavitation effects & {$[35]$} \\
\hline & Kidney & Long-term alterations on magnetic resonance imaging & {$[68]$} \\
\hline
\end{tabular}

SW, shock waves

using fluorescent dyes and analysis in a flow cytometer. The results are summarized in Fig. 1 (lower curve), in which the viable cells are plotted against the applied number of shock waves.

Suspensions of $L 1210$ cells that had been treated with 500 shocks waves revealed various degrees of damage under light micorscopy. Besides a high amount of fragmented cells and cell debris, irregular cells shapes and cytoplasmic vacuolisation were observed. Closer inspection with an electron microscope (Fig. 2) revealed swollen mi- tochondria with distorted cristae, swollen endoplasmatic reticulum, and a separation of the nuclear envelope.

L 1210 cell suspensions were also used for characterizing and quantifying the shock-wave efficacy. Using this assay, we could measure the influence of different parameters such as water-bath temperature, oxygen content, test-tube material, and suspension media on the extent of cell damage [14]. Furthermore, L 1210 suspensions have been used to correlate biological effects with pressure measurements carried out using PVDF-needle hydro- 
Table 3. Effects of shock waves on cells in culture and on tumors

\begin{tabular}{|c|c|c|}
\hline Cells & Results & References \\
\hline Whole blood & $\begin{array}{l}\text { In vitro: dose-dependent hemolysis; in vivo: no increase in free plasma hemoglobin in canine } \\
\text { peripheral blood }\end{array}$ & [17] \\
\hline Human neutrophils & $\begin{array}{l}\text { In suspensions: cellular disruptions, swelling of mitochondria, plasma-membrane ruptures: } \\
\text { changes in permeability and cytoskeleton }\end{array}$ & {$[40]$} \\
\hline Human melanoma & $\begin{array}{l}\text { Reduction in cell viability, decrease in colony formation, selective diminution of cells in G2 and } \\
\text { M phases }\end{array}$ & [73] \\
\hline $\begin{array}{l}\text { Human renal carcinoma, } \\
\text { normal human embryonic } \\
\text { kidney }\end{array}$ & $\begin{array}{l}\text { Dose-dependent reduction in viability, in vitro lysis, total inhibition of multiplication for } 5 \text { days } \\
\text { after } 2000 \mathrm{SW}\end{array}$ & {$[18]$} \\
\hline Human cervical carcinoma & $\begin{array}{l}\text { No influence on cell cycle, } 10 \text {-fold increase in growth inhibition when treated at } 18^{\circ} \text { vs } 37^{\circ} \text { and } \\
42^{\circ} \mathrm{C}\end{array}$ & [7] \\
\hline Normal human bone marrow & $50 \%$ reduction in viable cells after $700 \mathrm{SW}$; decreased colony formation & [89] \\
\hline \multirow[t]{3}{*}{ Rat prostatic carcinoma } & $\begin{array}{l}\text { Reduction in cell viability, decrease in colony formation, selective diminution of cells in G2 and } \\
M \text { phases, delay of tumor growth after reimplantation. Swollen mitochondria, distorted cristae, in } \\
\text { vivo exposure had no distinct histopathological or ultrastructural effect }\end{array}$ & [72] \\
\hline & In suspensions: growth delay, ultrastructural damages; in vivo: growth delay & [51] \\
\hline & $\begin{array}{l}\text { Dose-dependent inhibition of cell viability and colony growth; cells pretreated with SW became } \\
\text { more sensitive to chemo- and immunotherapy }\end{array}$ & {$[62]$} \\
\hline Rat prostate tumor & No effect of primary growth and metastasis & [36] \\
\hline Mouse bladder tumor & $\begin{array}{l}\text { Palpable tumors were not affected by } 800 \text { or } 1400 \mathrm{SW} ; 2000 \mathrm{SW} \text { led to significant inhibition of } \\
\text { growth }\end{array}$ & [19] \\
\hline Mouse leukemia & In suspensions: dose-dependent damage; no effect on immobilized cells & {$[12,13]$} \\
\hline Mouse mammary tumor & In suspensions: dose-dependent damage; no effect on immobilized cells & {$[8,9]$} \\
\hline
\end{tabular}

SW, shock waves

phones [16]. Suspended human erythrocytes may be used as another bioassay for the quantification of shock-wave efficacy. This assay is based on a photometric determination of free hemoglobin in the supernatant of shockwave-exposed human erythrocytes [15].

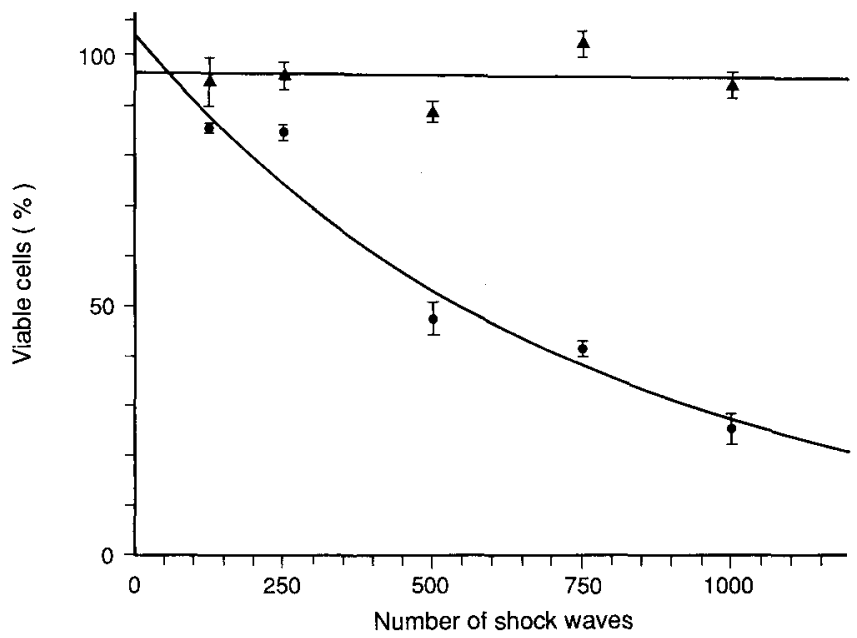

Fig. 1. Effect of shock waves on the viability of L 1210 mouse leukemia cells. Lower curve, single-cell suspension; upper curve, cells immobilized in gelatin
The question has been raised as to whether cancer can be cured by direct exposure to focused shock waves [65, 84]. We therefore also investigated the sensitivity of normal and malignant cells to shock waves under controlled and constant experimental conditions. Although these cell lines differ in their dose response, no specific or significant difference between normal and malignant cells was observed, as can be seen in Table 4.

A satisfactory approach to the spatial growth of cells in an organism is provided by multicell spheroids $[59,80]$, which therefore seem to be an appropriate model for investigating the biological effects of shock waves (Figs. 3, 4). Treatment of multicell spheroids in suspensions led to severe damage to these aggregates, which were completely fragmented at higher shock-wave doses. The defects depended on the morphological properties and the age of the multicell spheroids. Under comparable conditions, multicell spheroids of epitheloid HeLa cells were more severely damaged than those of fibroblastoid EMT6/Ro cells. Older multicell spheroids, which are segmented into a vital outer rim and a necrotic center, were more frequently fragmented than those with vital cells alone. Histological investigations of shock-wave-treated multicell spheroids revealed the same cellular destruction that we found in single-cell suspensions. 

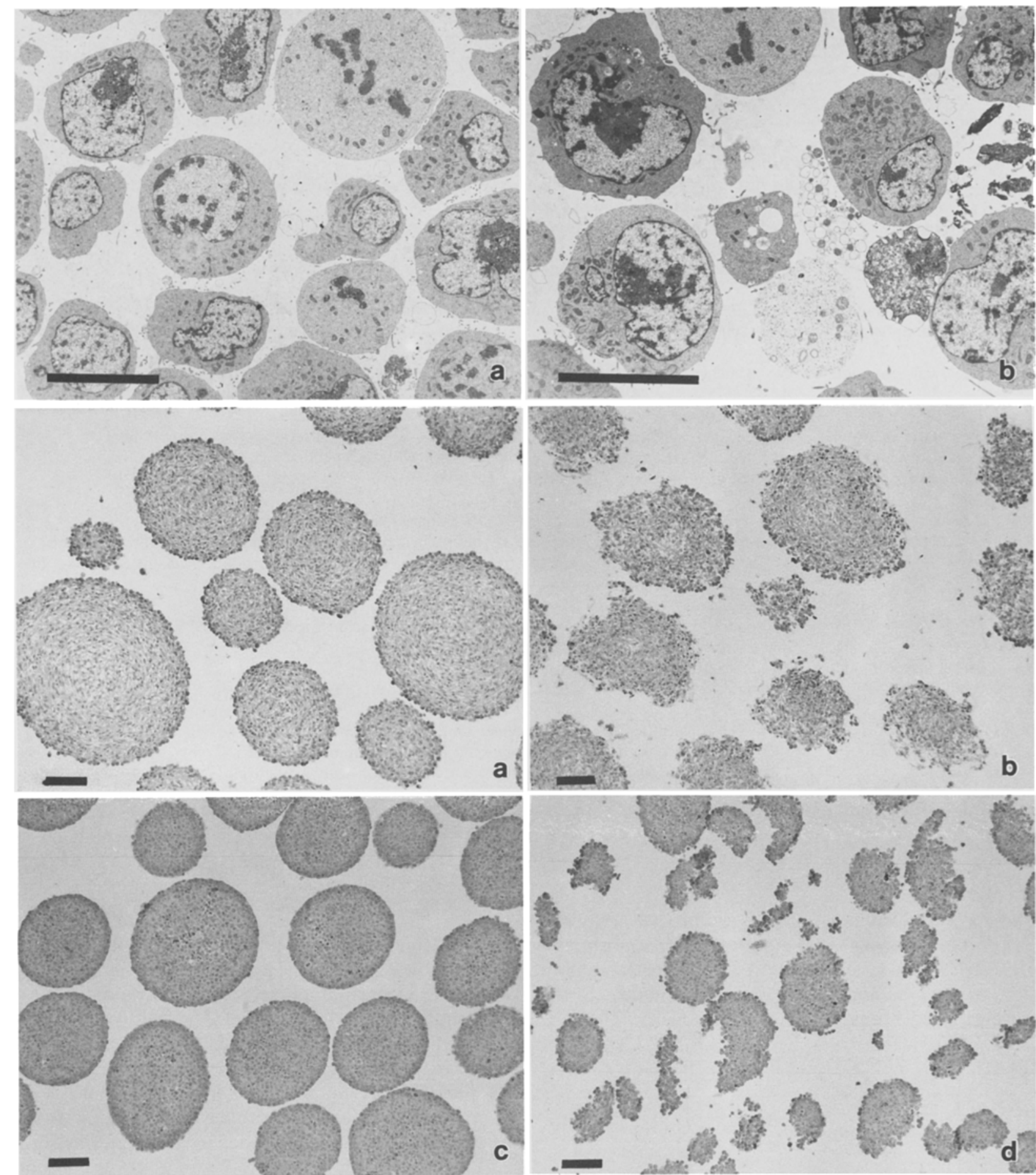

45
$\vdots$
$\vdots$
$\vdots$

और
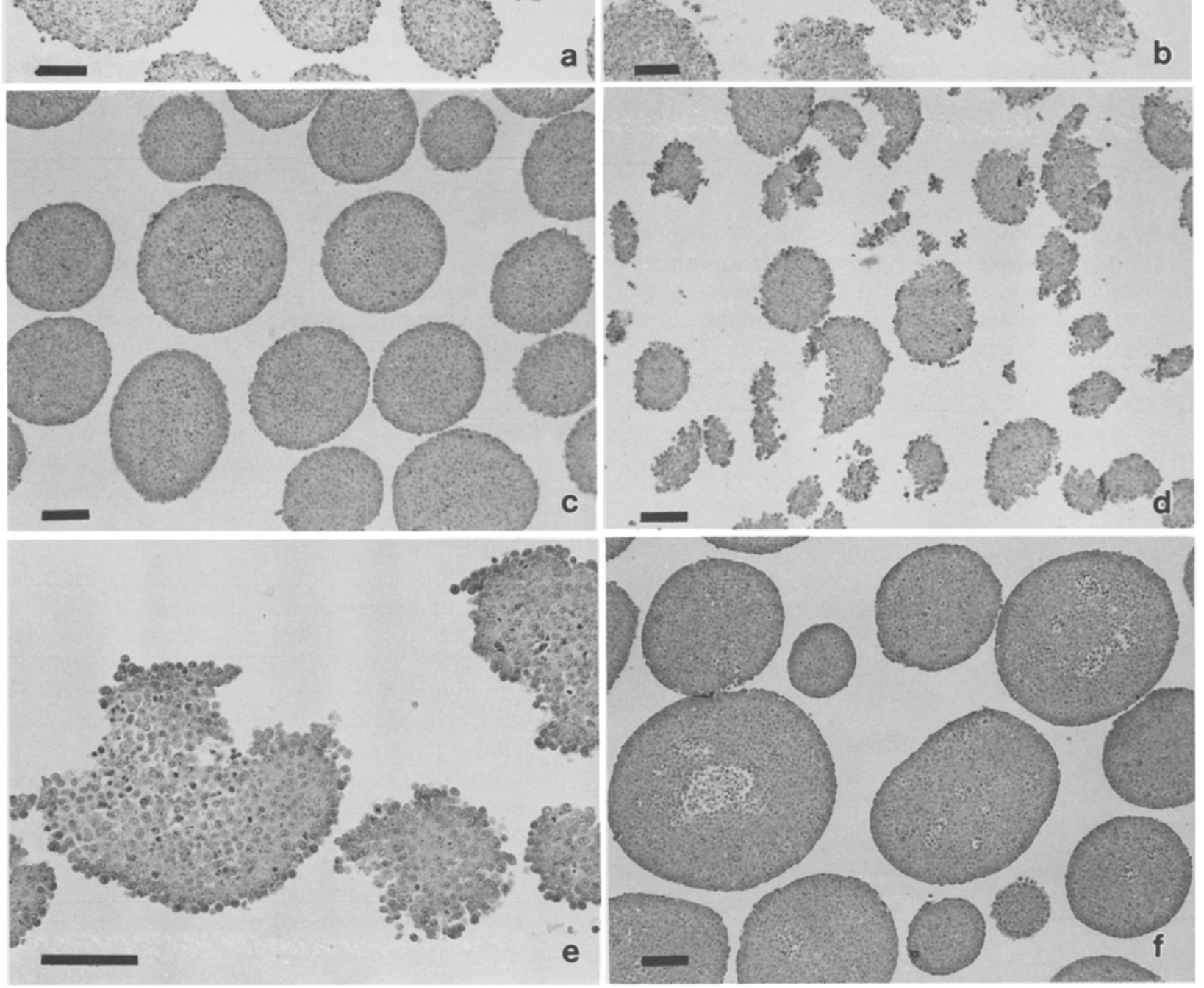
Fig. 2a,b. Electron micrographs of suspended L 1210 mouse leukemia cells. a Control, b Cells treated with 500 shock waves. Bars $10 \mu \mathrm{m}$

Fig. 3a-f. Light-microscope histology of multicell spheroids. Mouse mammary tumor EMT6 in suspension: a control; b spheroids treated with 500 shock waves. Human cervical carcinoma HeLa in suspension: c control; d, e spheroids treated with 500 shock waves; f spheroids embedded in $12 \%$ gelatin and then treated with 500 shock waves. Bars $100 \mu \mathrm{m}$
During shock-wave treatment of multicell spheroid suspensions, considerable agitation of the cells can be observed (Fig. 5); this may be the result of cavitation, which is caused in fluids by shock waves [22]. However, not only cavitation but also jet streams, which occur due to a local acceleration of the fluid in the focus of shock waves, of cells can lead to this vigorous agitation [58]. These rapid accelerations expose suspended cells to shear forces and cause collisions that may be responsible for cellular dam-
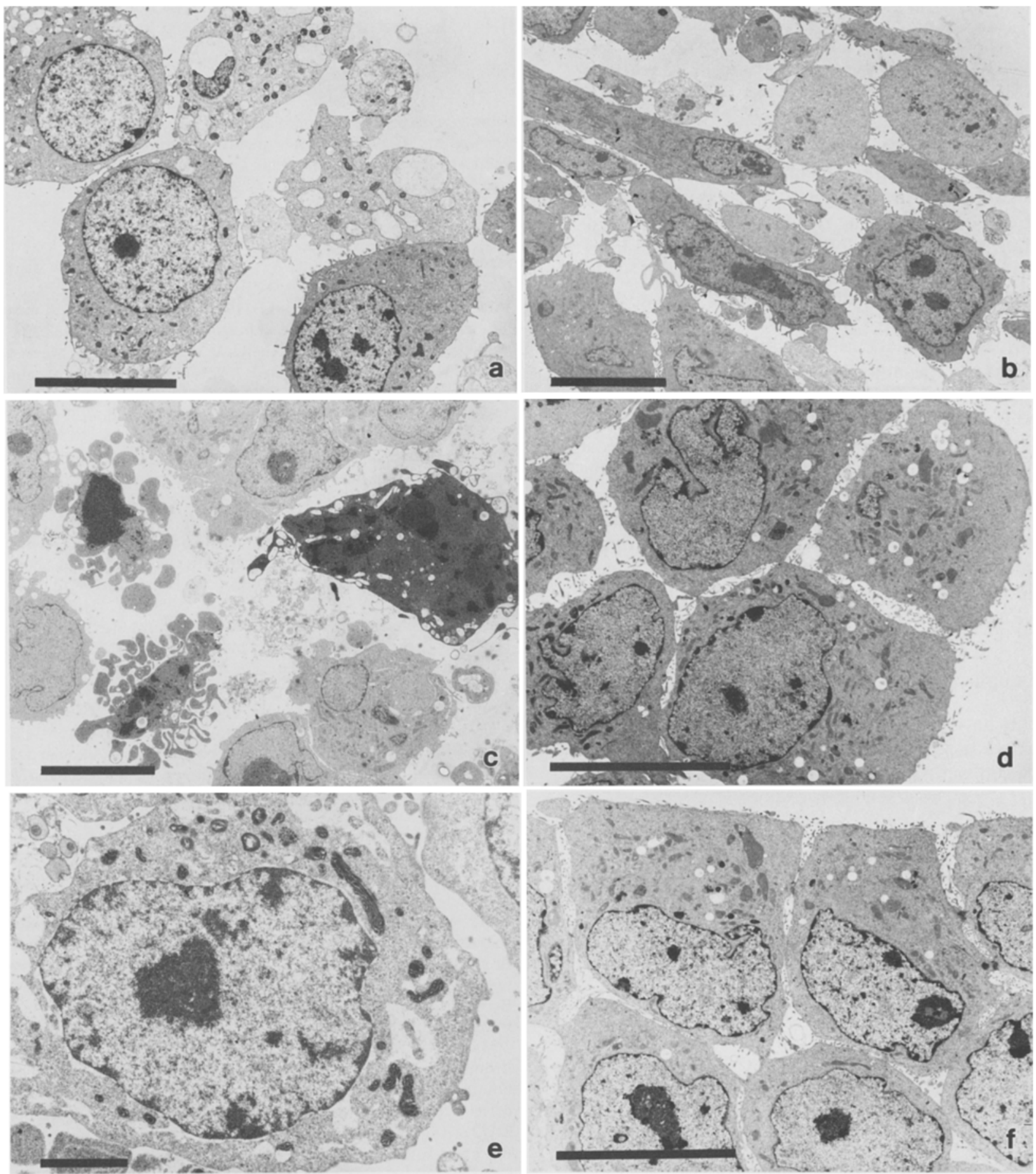

Fig. 4a-f. Electron-microscope histology of multicell spheroids. Mouse mammary tumor EMT6: a suspended spheroids after treatment with 500 shock waves; b immobilized spheroids in gelatine after treatment with 500 shock waves. Human cervical carcinoma HeLa: c, e sus-

pended spheroids after treatment with 500 shock waves; $d$ immobilized spheroids in gelatin after treatment with 500 shock waves; $f$ immobilized spheroid controls. Bars: e $2 \mu \mathrm{m} ; \mathbf{a}-\mathbf{d}, \mathbf{f}, 10 \mu \mathrm{m}$ 
Table 4. Sensitivity of malignant and normal cells in culture to shock waves

\begin{tabular}{ll}
\hline Cells & $\begin{array}{l}\mathrm{LD}_{50} \\
\text { (shock waves) }\end{array}$ \\
\hline MGHU-1 human bladder tumor & 433 \\
FL human amnion & 371 \\
Embryonic chicken-thigh muscle & 357 \\
L1210 mouse leukemia & 297 \\
F9 mouse teratocarcinoma & 282 \\
BICR/M1 R $_{\mathrm{k}}$ rat mammary carcinoma & 255 \\
Embryonic chicken kidney & 250 \\
\hline
\end{tabular}

$\mathrm{LD}_{50}$ values were calculated by regression analysis of the doseresponse curves

age. Furthermore, they may also explain why cellular injuries in vivo are found in small capillaries and in interstitial cavities rather than in larger blood vessels, in which hemolysis can occur but may not be detectable as an increase in free plasma hemoglobin in the peripheral blood.

In vitro, these secondary effects can be avoided by the immobilization of single cells or multicell spheroids in gelatin (see Figs. $3 \mathrm{f}$ and $4 \mathrm{~b}, \mathrm{~d}, \mathrm{f}$ ) $[9,13]$. Unter this condition, significant dose-dependent cellular damage was no longer detectable using flow cytometric techniques (Fig. 1, upper curve). This is consistent with the abovementioned results, whereby solid tissues remain unaffected by shock-wave treatment for most physiological and/or histological test procedures under in vivo conditions. However, the question as to whether immobilized cells (solid tissues) postioned in the focal area show transient changes due to shock-wave treatment remains open. Since immobilized, shock-wave-treated multicell spheroids show a decrease in intercellular contact sites (Fig. 4d), long-term effects cannot be excluded.

\section{Extended application of shock waves}

Experiments have been carried out to treat in vivo tumors with shock waves [36]. No decrease in tumor volume was observed when well-submersed animals were treated [65,

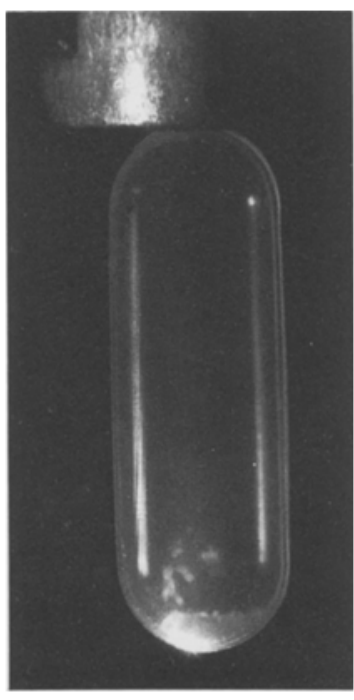

Fig. 5. Agitation of HeLa multicell spheroids in a polyethylene pipette (diameter, $1.3 \mathrm{~cm}$ ) exposed to a single shock wave (stroboscopic illumination)
85]; the addition of cytostatics resulted in inhibition of tumor growth [65, 85]. A more dramatic effect was achieved when the water surface was only $1 \mathrm{~cm}$ above the tumor: no tumor regrowth was observed [26]. Using highenergy ultrasound, similar cytotoxic effects on rodent tumors were described $[38,63,69,70]$. These results indicate that the application of shock waves could be extended beyond stone fragmentation. However, this would requires sophisticated modifications of the shock-wave generator as has previously been proposed by Eisenmenger [33] for the electromagnetic shock-wave emitter.

Acknowledgments. The excellent technical assistance of Ms. Susan Becker and Ms. Beate Rehkopf is greatly appreciated. This work was supported by Dornier Medizintechnik GmbH and the Bundesministerium für Forschung und Technologie (0318891 A).

\section{References}

1. Abrahams C, Lipson SB, Ross LS (1988) The effects of shock wave lithotripsy (ESWL) on canine kidneys (abstract). J Urol 139:324

2. Arduan J, Garcia-Gamez A, Cebezas J, Morales Lopez A, Maestro Duran JL, Cabezas J, Carcelan F (1988) Renal (extra-intra) morphology before and after ESWL, evaluated by magnetic resonance imaging. Abstract $0-5,6$ th World Congress on Endourology and ESWL, Paris, 1.-3. 9. 1988

3. Baba S, Hata M, Nakanoma T, Tazaki H (1988) Long-term bioeffects of extracorporeal shock waves on rat kidneys. Abstract 90 , 21 st Congress of the International Society of Urology, Buenos Aires, 9.-14. 10. 1988

4. Baumgartner BR, Dickey KW, Ambrose SS, Walton KN, Nelson RC, Bernardino ME (1987) changes after extracorporeal shock wave lithotripsy: appearance on MR imaging. Radiology 163:531-534

5. Begun FP, Lawson RK (1989) Long term effects of electrohydraulic shock waves on renal function and blood pressure. Abstract, 07-2, 7th World Congress on Endourology and ESWL, Kyoto, 27.-30. 11. 1989

6. Begun FP, Lawson RK, Kearns CM, Thieu TM (1989) Electrohydraulic shock wave induced renal injury. J Urol 142:155-159

7. Berens ME, Schostock C, Hart L, Barshira Z, McCullough DL (1988) Effect of cell cycle and temperature on the antiproliferative effects of acoustic shock waves (SW) against human tumor cells (abstract). J Urol 139:304

8. Bräuner Th, Brümmer F, Hülser DF (1988) Einwirkung von Stoßwellen auf tierische Zellkulturen. Licht- und elektronenmikroskopische Untersuchungen (abstract). Biomed Tech (Berlin) [Suppl 2]:35

9. Bräuner Th, Brümmer F, Hülser DF (1989) Histopathology of shock wave treated tumor cell suspensions and multicell tumor spheroids. Ultrasound Med Biol 15:451-460

10. Brendel W, Delius M, Goetz A (1987) Effect of shock waves on the microvasculature. Prog Appl Microcirc 12:41-50

11. Brewer SL, Atala AA, Ackerman DM, Steinbock GS (1988) Shock wave lithotripsy damage in human cadaver kidneys. J Endourol 2:333-339

12. Brümmer F, Bräuner Th, Brenner J, Hülser DF (1988) Effects of lithotripter-generated shock waves on $\mathrm{L} 1210$ mouse leukemia cells detected by flow cytometry (abstract). Eur J Cell Biol 46 [Suppl 22] 12

13. Brümmer F, Brenner J, Bräuner Th, Hülser DF (1989) Effect of shock waves on suspended and immobilized L 1210 cells. Ultrasound Med Biol 15:229-239

14. Brümmer F, Nesper M, Schiess K, Suhr D, Brenner J, Bräuner Th, Hülser DF (1989) Shock wave efficacy measured with a bioassay (abstract). Eur J Cell Biol 48 [Suppl 26]9 
15. Brümmer F, Nesper M, Schiess K, Suhr D, Brenner J, Hülser DF (1989) Characterisation of shock wave efficiency with cell cultures. Abstract P 13-5, 7th World Congress on Endourology and ESWL, Kyoto, 27,-30. 11. 1989

16. Brümmer F, Staudenraus J, Nesper M, Suhr D, Eisenmenger W, Hülser DF (1989) Biological effects and physical characterization of shock waves generated by an XL-1 experimental lithotripter. Proc Ultrasonics Int 89:1130-1135

17. Chaussy Ch, Schmied E, Jocham D, Fuchs G, Brendel W, Forssman B, Hepp W (1986) Extracorporeal shock wave lithotripsy. Karger, Basel

18. Chaussy ChG, Randazzo RF, Fuchs GJ (1986) The effects of extracorporeal shock waves on human renal carcinoma cells and normal human embryonic kidney cells (abstract). J Urol 139:320

19. Chaussy ChG, Randazzo RF, Fuchs GJ (1986) The effects of extracorporeal shock waves on FANFT bladder tumors in $\mathrm{C} 3 \mathrm{H} / \mathrm{He}$ mice (abstract). J Urol 139:289

20. Chinn SKB, Michaels EK, Fowler JE, Behnia R, Linde HW, Ray V (1988) Hemodynamic and adrenal response to shock wave energy (abstract). J Urol 139:324

21. Cole RS, Montgomery BSI (1989) The incidence of hypertension 29 months after renal ESWL. Abstract 07-3, 7th World Congress on Endourology and ESWL, Kyoto, 27.-30. 11. 1989

22. Coleman AJ, Saunder JE, Crum LA, Dyson M (1987) Acoustic cavitation generated by an extracorporeal shockwave lithotripter. Ultrasound Med Biol 13:69-76

23. Das G, Birch B, Garden P, Wickham JEA (1988) The biological effects of shockwave lithotripsy. Abstract 0-17, 6th World Congress on Endourology and ESWL, Paris, 1.-3. 9. 1988

24. Delius M, Enders G, Heine G, Stark J, Remberger K, Brendel W (1987) Biological effects of shock waves: lung hemorrhage by shock waves in dogs - pressure dependence. Ultrasound Med Biol 13:61- 67

25. Delius M, Enders G, Xuan Z, Liebich HG, Brendel W (1988) Biological effects of shock waves: kidney damage by shock waves in dogs - dose dependence. Ultrasound Med Biol 14:117-122

26. Delius M, Weiss N, Gambihler S, Goetz A, Brendel W (1989) Tumor therapy with shock waves requires modified lithotripter shock waves. Naturwissenschaften 76:573-574

27. Di Cello V, Selli C, Fiorelli C, Nicita G, Carini M, Saltutti C, Fontanelli A, Rosi E, Doni A (1988) Study of fibrinolytic system changes following ESWL. Abstract 0-15, 6th World Congress on Endourology and ESWL, Paris, 1.-3. 9. 1988

28. Drach GW (1988) Side effects of shock-wave lithotripsy - an overview. Abstract 92, 21st Congress of the International Society of Urology, Buenos Aires, 9.-14. 10. 1988

29. Eisenberger F, Rassweiler J (1986) Extrakorporale Stoßwellenlithotripsie im Wandel. Akt Urol 17:229-233

30. Eisenberger F, Fuchs GJ, Gumpinger R, Miller K, Rassweiler J (1987) Urologische Steintherapie - ESWL und Endourologie. Thieme, Stuttgart

31. Eisenmenger W (1961) Eine elektromagnetische Impulsschallquelle zur Erzeugung von Druckstößen in Flüssigkeiten und Festkörpern. Proceedings of the 3rd International Congress on Acoustics, Stuttgart, 1959, 326-329

32. Eisenmenger W (1962) Elektromagnetische Erzeugung von ebenen Druckstößen in Flüssigkeiten. Acustica 12:185-202

33. Eisenmenger W (1988) Methoden der Stoßwellenerzeugung und -messung. Biomed Tech (Berlin) 33 [Suppl 2] 1-6

34. Ell C, Kerzel W, Heyder N, Rödl W, Langer H, Mischke U, Giedl J, Domschke W (1989) Tissue reactions under piezoelectric shockwave application for the fragmentation of biliary calculi. Gut 30:680-685

35. Fischer N, Müller HM, Gulhan A, Sohn M, Deutz FJ, Rubben H, Lutzeyer W (1988) Cavitation effects: possible cause of tissue injury during extracorporeal shock wave lithotripsy. $\mathrm{J}$ Endourol 2:215-220

36. Geldof AA, Voogt HJ de, Rao BR (1989) High energy shock waves do not affect either primary tumor growth or metastasis of prostate carcinoma, R 2237-MatLyLu. Urol Res 17:9-12

37. Grote R, Döhring W, Aeikens B (1986) Computertomographischer und sonographischer Nachweis von renalen und perirenalen Veränderungen nach einer extrakorporalen Stoßwellenlithotripsie. Fortschr Röntgenstr 144:434-439

38. Hahn EW, Riedlinger R, Mattern J, Ueberle W, Bak M, Peschke P, Lorenz A, Zuna I, Gerlach L, Volm M, Kaick G van, Lorenz WJ (1988) High energy pulsed ultrasound (HEPUS): cytotoxic effects on rodent tumors. Biomed Tech (Berlin) 33 [Suppl 2]141-142

39. Haupt G, Haupt A, Donovan JM, Drach GW, Chaussy Ch (1989) Short-term changes of laboratory values after extracorporeal shock wave lithitropsy: a comparative study. I Urol 142:259-262

40. Holmes RP, Yeaman LD, Taylor RG, Lewis JC, McCullough DL (1988) Enhanced Adriamycin uptake by neutrophils exposed to shock waves (abstract). J Urol 139:304

41. Hülser DF, Brümmer F, Brenner J, Bräuner Th, Nesper M (1988) Zell- und Gewebsveränderungen durch eine Stoßwellenbehandlung. Biomed Tech (Berlin) 33 [Suppl 2]:7-10

42. Jaeger P, Deslarzes C, Ginalski JM (1988) Evidence by ureteral catheterization of subtile renal tubular dysfunction after ESWL. Abstract 0-8, 6th World Congress on Endourology and ESWL, Paris, 1.-3. 9. 1988

43. Jaeger P, Redha F, UhlschmidG, Hauri D (1988) Morphological changes in canine kidneys following extracorporeal shock wave treatment. J Endourol 2:205-213

44. Janssens J, Baert L, De Geest H, Ector H (1988) Extracorporeal shock wave lithotripsy and cardiac arrhytmias. Abstract 0-14. 6th World Congress on Endourology and ESWL, Paris, 1.-3. 9. 1988

45. Kaude JV, Williams CM, Millner MR, Scott KN, Finlayson B (1985) Renal morphology and function immediately after extracorporeal shock-wave lithotripsy. AJR 145:305-313

46. Kishimoto T, Yamamoto K, Sugimoto T, Yoshihara H, Maekawa M (1986) Side effects of extracorporeal shock-wave exposure in patients treated by extracorporeal shock-wave lithotripsy for upper urinary tract stone. Eur Urol 12:308-313

47. Knapp PM, Kulb TB, Lingeman JE, Newman DM, Mertz JHO, Mosbaugh PG, Steele RE (1988) Extracorporeal shock wave lithotripsy-induced perirenal hematomas. J Urol 139:700-703

48. Krongrad A, Saltzman B, Tannenbaum M, Droller MJ (1988) Enzymuria following extracorporeal shock wave lithotripsy (ESWL) (abstract). J Urol 139:324

49. Kurzweil SJ, Smith JE, Arsdalen K van (1988) Effects of extracorporeal shock waves on skeletal and renal growth in the infant rabbit (abstract). J Urol 139:325

50. Lingeman JE, Kulb TB (1987) Hypertension following extracorporeal shock wave lithitripsy (abstract). J Urol 137:142

51. Loening SA, Mardan AH, Holmes J, Lubaroff DM (1988) In vivo and in vitro effects of shock waves on dunning prostate tumors (abstract). J Urol 139:303

52. Loening SA, Mardan AH, Lubaroff DM (1988) In vivo pathological effects of high energy shock waves generated by an experimental extracorporeal shock wave lithotripter (abstract). J Urol 139:323

53. Marcellan R, Servio LI (1986) Evaluation of renal damage in extracorporeal lithotripsy by shock waves. Eur Urol 12:73-75

54. Mardan A, Loening S (1988) Pathological reactions in rats to highenergy shock waves: 1 . Local tissue responses. Abstract $0-51,6$ th World Congress on Endourology and ESWL, Paris, 1.-3. 9. 1988

55. Mardan A, Loening S (1988) Pathological reactions in rats to highenergy shock waves: 2. Systemic responses. Abstract O-52, 6th World Congress on Endourology and ESWL, Paris, 1.-3. 9. 1988

56. McCullough DL, Yeaman LD, Bo WJ, Assimos DG, Kroovand RL, Griffin AS, Furr EG (1988) Do extracorporeal shock waves affect fertility and fetal development? A study of shock wave effects on the rat ovary and fetus (abstract). J Urol 139:325

57. Morgan RT, Laudone VP, Heston WDW, Zeitz L, Fair WR (1988) Free radical production by high energy shock waves - comparison with ionizing irradiation. J Urol 139:186-189

58. Müller M (1987) Stoßwellenfokussierung in Wasser. Ph D thesis, RWTH Aachen, FRG

59. Müller-Klieser W (1987) Multicellular spheroids. A review on cellular aggregates in cancer research. J Cancer Res Clin Oncol 113:101- 122

60. Newman DM, Lingeman JE, Woods JR, Toth PD (1989) Blood 
pressure changes following extracorporeal shock wave lithotripsy and other forms of treatment for urolithiasis. Abstract 07-4, 7th World Congress on Endourology and ESWL, Kyoto, 27.-30. 11. 1989

61. Newman R, Hackett R, Senior D, Brock B, Feldman J, Sosnowski J, Finlayson B (1987) Pathologic effects of ESWL on canine renal tissue. Urology 29:194-200

62. Oosterhof GON, Smits GAHJ, Ruyter JE de, Morselaar RJA, Schalken JA, Debruyne FMM (1989) The in vitro effect of electromagnetically generated shock waves (Lithostar) on the Dunning R3327 PAT-2 rat prostatic cancer cell-line. Urol Res 17:13-19

63. Peschke P, Hahn EW, Lorenz WJ, Debus J, Zabel HJ, Ifflaender H, Lorenz A, Kaick G van, Pfeiler M (1989) Pulsed high energy ultrasound shock-waves (PHEUS): biological effects on the Dunning prostate rat tumor. Abstract P 13-7, 7th World Congress on Endourology and ESWL, Kyoto, 27.-30. 11. 1989

64. Ponchon T, Barkun AN, Berger F, Ayela P, Margonari J, Capron F (1989) Experimental tissue lesions related to extracorporeal lithotripsy of gallbladder. Surg Gynecol Obstet 169:435-441

65. Randazzo RR, Chaussy CG, Fuchs GJ, Bhuta SM, Lovrekovich H, de Kernion JB (1988) The in vitro and in vivo effects of extracorporeal shock waves on malignant cells. Urol Res 16:419-426

66. Rassweiler J, Westhauser A, Bub P, Eisenberger F 81988) Secondgeneration lithitropters: a comparative study. J Endourol 2:193-204

67. Recker F, Rübben H, Hofstädter F, Bex A (1988) Ultramorphological acute and long term lesions of ESWL in rat kidney. Abstract 0-54, 6th World Congress on Endourology and ESWL, Paris, 1.-3. 9. 1988

68. Recker F, Ruebben H, Neuerburg J, Bex A, Deutz FJ, Hofstaedter F (1990) Magnetic resonance imaging of acute and long-term alterations following extracorporeal shock wave lithotripsy in rats. Urol Int $4: 28-33$

69. Riedlinger R, Ueberle F, Zanger U (1988) HEPUS (high energy pulsed ultrasound): apparatus and physical aspects of tumor-insonification. Biomed Tech (Berlin) 33 [Suppl 2]:139-140

70. Riedlinger RE, Brümmer F, Hülser DF (1989) Pulsed high-power-sonication of concrements, cancer cells and rodent-tumors in vivo. Proc Ultrasonics Int 89:305-312

71. Rubin JI, Arger PH, Pollack HM, Banner MP, Coleman BG, Mintz MC, Van Arsdalen KN (1987) Kidney changes after extracorporeal shock wave lithotripsy: CT evaluation. Radiology 162:21-24

72. Russo P, Stephenson RA, Mies C, Huryk R, Heston WDW, Melamed MR, Fair WR (1986) High energy shock waves suppress tumor growth in vitro and in vivo. J Urol 135:626-628

73. Russo P, Mies C, Huryk R, Heston WDW, Fair WR (1987) Histopathologic and ultrastructural correlates of tumor growth suppression by high energy shock waves. J Urol 137:338-341

74. Saitoh T, Ioritani N, Kuwahara M, Shirai S, Kambe K, Taguchi K, Orikasa $S$ (1989) Chronic changes of renal tissue exposed to focused shock waves. Abstract P11-15, 7th World Congress on Endourology and ESWL, Kyoto, 27.-30. 11. 1989
75. Schneider HT, Ell C (1989) Schmerzreaktion: Systemvergleich. Oral presentation, Meeting on Medical Technology, Berlin, 6.-11. 11. 1989

76. Schulze H, Falkenberg F, Mondorf AW, Engelmann U, Senge Th (1988) Enhanced excretion of kidney-derived antigens in the urine of patients after ESWL treatment (abstract). J Urol 139:323

77. Steele R (1988) Blood pressure changes following ESWL. Abstract 0-12, 6th World Congress on Endourology and ESWL, Paris, 1.-3. 9. 1988

78. Steinmann J, Wilbert DM, Strohmeier WL, Flüchter SH, Bichler KH (1988) Glomerular and tubular changes after extracorporeal shock wave lithotripsy measured by urinary proteins. Abstract 0-9, 6th World Congress on Endourology and ESWL, Paris, 1.-3. 9. 1988

79. Stephenson TJ, Johnson AG, Ross B (1989) Short-term effects of extracorporeal shock wave lithotripsy on the human gallbladder. J Pathol 158:239-246

80. Sutherland RM (1988) Cell and environment interactions in tumor microregions: the multicell spheroid model. Science 240:177-184

81. Tashiro K, Mochizuki A, Machida T (1988) Renal tissues damaged by piezoelectric shock waves. Abstract 0-55, 6th World Congress on Endourology and ESWL, Paris, 1.-3. 9. 1988

82. Thomas R, Sloane B, Roberts J (1988) Long-term effect of extracorporeal shock wave lithotripsy on renal function. Abstract 0-11, 6th World Congress on Endourology and ESWL, Paris, 1.-3. 9. 1988

83. Tiselius HG, Eriksson I, Sandvall K (1989) Is blood pressure affected by ESWL-treatment? Abstract 05-5, 7th World Congress on Endourology and ESWL, Kyoto, 27.-30. 11. 1989

84. Van Dongen JW, Van Steenbrugge GJ, Romijn JC, Schröder FH (1989) The cytocidal effect of high energy shock waves on human prostatic tumour cell lines. Eur J Cancer Clin Oncol 25:1173-1179

85. Weiss N (1989) Verstärkung der Zytostatika-Wirkung durch Stoßwellen. Oral presentation, Körber-Stiftung Symposium „Stoßwellen-Anwendungen in der Medizin“, München, 16. 2. 1989

86. Williams AR, Delius M, Miller DL, Schwarze W (1989) Investigation of cavitation in flowing media by lithotripter shock waves both in vitro and in vivo. Ultrasound Med Biol 15:53-60

87. Williams CM, Kaude JV, Newman RC, Peterson JC, Thomas WC (1988) Extracorporeal shock-wave lithotripsy: long-term complications. AJR 150:311-315

88. Wilmer A, Gambihler S, Delius M, Brendel W (1989) In vitro cytotoxic activity of lithotripter shock waves combined with Adriamycin or with cisplatin on L1210 mouse leukemia cells. J Cancer Res Clin Oncol 115:229-234

89. Yang C, Heston WDW, Gulati S, Fair WR (1988) The effect of high energy shock waves (HESW) on human bone marrow. Urol Res $16: 427-429$

90. Yeaman LD, McCullough DL, Jerome CP (1988) Effects of extracorporeal shock waves on immature bone growth of the rat (abstract). J Urol 139:324 